\title{
The 1967 Applied Superconductivity \\ Conference Program
}

\author{
November 6-8, 1967 \\ presented by \\ The College of Engineering of The University of Texas \\ and \\ The Atomic Energy Commission
}

\section{SESSION I ….OPENING SESSION}

- Conference Welcome

Dr. Norman Hackerman

The University of Texas

- The Bureau of Mines Helium Program

Dr. W. H. Hibbard

Bureau of Mines, U. S. Department of the Interior

- Government Programs in Superconductivity Dr. B. W. Birmingham

Institute for Materials Research, National Bureau of Standards

- Superconductivity in Europe

Dr. Bruce B. Goodman

British Oxygen Company

\section{SESSION IIA …...PHYSICS REVIEWS}

- Pair Breaking Mechanisms in Superconductors R. D. Parks

University of Rochester

- Tunneling and Weak-Link Superconductor Phenomena Having Potential Device Applications

D. E. McCumber

Bell Telephone Laboratories

- Superconductive Phenomena in Ultra-Thin Films

M. Strongin

Brookhaven National Laboratory

- High Temperature Superconductors

T. H Geballe

Bell Telephone Laboratories

- Vortex Flow in Superconductors

G.B. Yntema
United Aircraft Research Laboratories

- Device Applications of the Josephson Effects :

A Review

B. N. Taylor

RCA Laboratories

- Superconducting Magnets for High Energy

Physics

H. Brechna

Stanford Linear Accelerator Center

SESSION IIB ….MAGNET MATERIALS

- Superconducting Materials

C. Laverick

Argonne National Laboratory

- Fully Stabilized Superconducting Strip for the Argonne and Brookhaven Bubble Chambers J. Wong, D. F. Fairbanks, R. N. Randall and W. L. Larson

Supercon Division, National Research Corp., - Improved Stabilized Superconductors

A. El Bindari and R. E. Bernert

Avco Everett Research Laboratory

- Mechanical and Electrical Properties of Diffusion Processed $\mathrm{Nb}_{3} \mathrm{Sn}$-Copper-Stainless Steel Composite Conductors

M. G. Benz

General Electric Company

- Vapor Deposited $\mathrm{Nb}_{3} \mathrm{Sn}$ Ribbons

H. C. Schindler

Special Electronic Components Division, RCA

- Angular Dependence of Critical Currents in Plasma-Plated $\mathrm{Nb}_{3} \mathrm{Sn}$-Strip Superconductors W. A Fietz

Union Carbide Corporation, Speedway Labora. tories 
- Microstructure Effects inTi-22 A\% Nb Conductors

D. Kramer

Atomics International

- Superconductivity Critical Current Densities in Ti-V Alloys

J. B. Vetrano, G. L. Guthrie and H. E. Kissinger Batelle-Northwest

- Fast Neutron Irradiation Effects in Superconducting Niobium

S. T. Sekula and R.H. Kernohan

Oak Ridge National Laboratory

\section{SESSION IIIA ….PHENOMENA}

- AC Losses in Superconductors

S. L. Wipf

Atomics International

- Macrovortex Structure in Hard Superconductors

Y. Iwasa and J.E.C. Williams

National Magnet Laboratory, MIT

- Flux Flow and Thermal Stability of Superconductors

W. F. Gauster, K. R. Efferson, J.B. Hendricks, D. M. Kroeger and M.S. Lubell

Oak Ridge National Laboratory

- Peak-Effect Studies on Niobium Nitride

E. Maxwell, B.B. Schwartz, H. Wizgall and

K. Hechler

National Magnet Laboratory, MIT

- RF Losses in the Superconducting Penetration Depth

J. M. Victor and W. H. Hartwig

The University of Texas

- Magnetic Transitions of Superconducting Thin Films and Foils of Lead

G. D. Cody and R.E. Miller

RCA Laboratories

- Granular Superconductors

R.W. Cohen and B. Abeles

RCA Laboratories

- Radiant Energy Detection by Superconducting Films

C. L. Bertin and K. Rose

Rensselaer Polytechnic Institute

\section{SESSION IIIB $\cdots \cdot$...COMPUTER DEVICES}

- A Multi-Aperture Cryogenic Storage Cell

J. L. Mundy and V. L. Newhouse

General Electric Co.,

$n$ Cryoelectric Content Addressable Memories Utilizing Flux Shuttling Nondestructive Readout

S. A. Keneman

RCA Laboratories

- The Cryoelectric Memory

J. Carrona

Cryoelectric Devices Laboratory, RCA

- Dynamic Fault Tolerance in Cryoelectric Arrays

J. P. Pritchard Jr. and B. G. Slay Jr.

Texas Instruments, Inc.,

- The Anisotropic Structured Cell : A Practical Cryoelectric Storage Element

R. A. Gange

Electronic Components and Devices, RCA

- Tunneling Cryotron Flip-Flop

J. Matisoo

IBM Watson Research Center

- Electronic Gray Matter

R. D. Parmentier and A. C. Scott

The University of Wisconsin

\section{SESSION IVA ….PHENOMENA AND DEVICES}

- Microwave and R. F. Studies of Type II Superconductors

J I. Gittleman

RCA Laboratories

- Microwave Studies of Thin Superconducting Films

D. A. Soderman and K. Rose

Rensselaer Polytechnic Institute

Some Rate Dependent Aspects of the Superconducting to Normal Transitions of Type II Materials

F. Rothwarf, G. Articola, G P. Segal and D. Ford

Pitman-Dunn Laboratories

Y.B. Kim 
Bell Telephone Laboratories

- Uses of High-Field Superconducting Magnets in Mossbauer Spectroscopy

R. L. Collins

The University of Texas

- Experimental Study of Superconducting TE011

Cavities at $2.868 \mathrm{GHz}$

H. Hahn and H J. Halama

Brookhaven National Laboratory

- Proposed Absolute Ammeter Using Flux Quantization

R. Meservey

National Magnet Laboratory, MIT

- Frequency and Time Domain Analysis of a Superconductive Coaxial Line Using the Two Fluid Model

W. D. McCaa Jr. and N.S. Nahman

National Bureau of Standards

\section{SESSION IVB $\cdots \cdot$...HIGH FIELD MAGNETS 1}

- The Superconducting Magnet for the ANL 12-Foot Hydrogen Bubble Chamber

J. R. Purcell

Argonne National Laboratory

- High-Homogeneity Tape-Wound Superconducting Coil

C.D. Graham Jr., H. R. Hart Jr. and E. F. Mains

General Electric Company

- Measurement Techniques for Superconducting Coils

E. F. Mains and C. D. Graham Jr.

General Electric Company

- Progress in Superconducting Beam Handling and Accelerator Structures since November 1966

P G. Kruger and J. N. Snyder

University of Illinois

W. B. Sampson

Brookhaven. National Laboratory

- A High-Field Superconducting Magnet

W. Wurz

Bell Telephone Laboratories

- A Partially Stable 90 Kilogauss Composite
Superconducting Solenoid

J. F. Becker and S. D. Lindenbaum

Grumann Aircraft Engineering Corp.

- Stabilized, Levitated Superconducting Rings.

J. File, G. D. Martin, R. G. Mills and J.L.

Upham

Plasma Physics Laboratory

\section{SESSION VA …HIGH FIELD \\ MAGNETS 2}

- The IMP Superconducting Plasma Facility of ORNL and General Problems in Designing Nonaxially Symmetrical Superconducting

Magnet Systems

W. F. Gauster and D. L. Coffey

Oak Ridge National Laboratories

- The Design of an 88 Kilogauss, 20-Inch Bore Superconducting Magnet System

E. J. Lucas and T. de Winter Avco Everett Research Laboratory

J. Laurence and W. Coles

NASA Lewis Research Center

- Results of Tests on Models for an $88 \mathrm{kG} \mathrm{20-}$ Inch Bore Diameter Solenoid

Z. J. J. Stekley, E. Lucas, T. de Winter and F. Di Salvo

Avco Everett Research Laboratory

- The Stabilization of High Current DensityHigh Field Superconductive Magnets

E. R. Schrader and P. A. Thompson

RCA

W. Coles

NASA Lewis Research Center

- The Transient Stabilization of $\mathrm{Nb}_{3} \mathrm{Sn}$-Composite Ribbon Magnets

J.R. Hale and J.E.C. Williams

National Magnet Laboratory, MIT

- Automatic Superconducting Switches

H. L. Laquer

Los Alamos Scientific Laboratory, University of California

- High Efficiency Superconducting Homopolar

DC Generators

D. Atherton, Ferranti-Packard Electric Ltd.

(17 頁につづく) 


\section{文献}

1) R.E. Honig and H. O. Hook: RCA Rev. 21 (1960) 360 より作成.

2) B. M. Bailey and R. L. Chuan : 19585 th Natl. Symp. Vac. Tech. Trans. (1959) 262 ; J. G. Everton : 1962 Trans. 9 th Natl. Vac. Symp. (1962) 227.

3）電試ニュース 175 号（1964 年 8 月）; 秋山好 原・橋本久子・石井博：真空 8 (1965) 299.

4) 電試ニニース 212 号 (1967 年 9 月); 秋山好 胤他: 第 1 回低温工学研究発表会 (42 年 11 月 1日); 石井博他：低温工学 2（1967）1.

5）後藤正敏・西田啓一・金原 粲: 第 14 回応用 物理連合講演会（1967 年 4 月 2 日）.

6) S. Brumaner and P. H. Emmett: J. Am. Chem. Soc. 59 (1937) 2682.

7) Dushman: Sci. Foundation of Vac. Tech. (John Wiley \& Sons, Inc.) p. 494.

8) L. O. Mullen and R. B. Jacobs : 1962 Trans. 9 th Natl. Vac. Symp. (1962) 220.

9) W.Bäckler, G. Klipping, and W. Mascher : ibid. 216.
10) J. P. Dawson, J. D. Haygood, and J. A. Collins: Adv. Cryo. Eng. 9 (1964) 443.

11) R. T. Brackmann et al: J. Chem. Phys. 34 (1961) 1572.

12）秋山好胤・石井博：第 1 回国際低温工学会議 (1967 年 4 月 10 日).

13) D. J. Santeler : General Electric Corp. 報告.

14）中山勝矢 - 秋山好糹 - 斎藤真人: 第 8 回真空に 関する連合講演会 (1967 年 10 月 14 日)

15) J. Richman and C. B. Hood : 1962 Trans. 9 th Nat1. Vac. Symp. (1962) 282.

16) D. J. Santeler : 19596 th Natl. Symp. Vac. Tech. Trans. (1960) 129.

17) B. S. Denhay : Proc. of the 1966 Symp. on Eng. Problem of Controlled thermonuclear research (1966) 367.

18) K. Keck, G. U. Schubert und H. Wiechert : 1965 Trans. 3rd Internatl. Vac. Cong. 2 (1966) 559.

19) J.C. Riviere, J.B. Thompson, J.E. Read and I. Wilson : ibid. 571.

20）中川洋：真空 3 (1960） $245 ; 7$ (1964) 54, 7 (1964) 367, 9 (1966) 164.

\section{SESSION VB …..JOSEPHSON AND}

\section{R. F. DEVICES}

- Superconductive Pressure Contacts

G. K. Gaule, J. T. Breslin and J. J. Winter

U.S. Army Electronics Command

- Surerconductive Microwave Meander Lines D. A. Gandolfo, A. Boornard and L. C. Morris Applied Research Department, RCA

- Frequency Conversion Using Weak MultiplyConnected Josephson Junctions

F. Rothwarf and H. M. Krisch Pitman-Dunn Laboratories

- High Sensitivity Superconducting Detector J.E. Zimmerman and A.H. Silver
Scientific Laboratory, Ford Motor Co.

- Relaxation Oscillations in Josephson Junctions F. L. Vernon Jr. and R. J. Pederson Aerospace Corporation

- Physics of Preparation of Josephson Barriers W. Schroen

Texas Instruments Inc.

- Photodielectric Detector Using a Superconducting Cavity

G. D. Arndt and W. H. Hartwig

The University of Texas

- Performance of Superconducting Oscillators and Fiters

J. L. Stone and W. H. Hartwig

The University of Texas 